DOI: $10.2478 /$ pts-2019-0002

\title{
OPTICAL PROPERTIES OF NEW TYPE OF GLAZING UNIT MODIFIED BY PHASE CHANGE MATERIAL (THEORETICAL APPROACH)
}

\author{
M. Vanags, K. Lebedeva, A. Snegirjovs, G. Kashkarova, P. Shipkovs \\ Institute of Physical Energetics \\ 11 Krivu Street, Riga, LV-1006, LATVIA
}

\begin{abstract}
The paper presents the use of phase change material (PCM) in window application that was studied in the framework of the ERA-NET-LAC Project "Solar Hybrid Translucent Component for Thermal Energy Storage in Buildings" (SOLTREN). Increase of energy savings in buildings is the main aim of this study. To achieve the aim, it has been decided to create a theoretical model of the impact of the PCM on the characteristics of the window and, at the next stage, to experimentally test the model. Paraffin has been chosen as the most suitable and available material as PCM. Pure paraffin has high transparency in liquid phase, and dull white colour in solid phase. The paper shows results of total transmittance and absorption spectra for different thicknesses of paraffin with a melting temperature of $35^{\circ} \mathrm{C}$, as well as absorption of the glass sample with PCM at different angles of incidence of light.
\end{abstract}

Keywords: energy savings in buildings, optical properties, phase change material, window glazing

\section{INTRODUCTION}

Most countries have significantly reduced their total energy use per unit of GDP over the past three decades. The decline in energy intensity has been driven largely by improved energy efficiency in key end-uses such as vehicles, appliances, space heating and industrial processes. Governments have implemented a wide range of policies and programmes such as energy efficiency standards, educational campaigns, obligations for market participants and financial incentives to accelerate the development and adoption of energy efficiency measures [1]. In this way, policies and programmes have helped improve energy efficiency and continue to develop technology in response to rising energy prices and increased competition in the energy sectors.

In all climatic conditions, it is very important to increase energy efficiency in buildings because in warm climate zones a high amount of energy is required for conditioning, but in cold climate zones for heat supply.

Most of the studies and applications have focused on the "opaque" part of 
building envelopes, such as walls, ceilings, and floors. However, we should notice one fact: generally speaking, "transparent" part of the building envelopes, i.e., window has much lower thermal resistance than other parts of the envelopes [2].

From the thermal point of view, windows represent the weak link between the internal and external ambient zones of a room. In cold climates, they are responsible for $10 \%-25 \%$ of the heat lost from the heated ambient to the external atmosphere [3].

Many scientists are working on these problems, but energy efficiency measures should not only increase the energy efficiency of buildings, but also maintain an appropriate micro climate in their premises. Currently, there are commercially available types of glazing such as Delta ${ }^{\circledR}-\mathrm{Cool} 28$ or Glass $\mathrm{X}^{\circledR}$ that incorporates phase change material (PCM) (the PCM incorporated in the GlassX products is comprised of $\mathrm{CaCl}_{2} \times 6 \mathrm{H}_{2} \mathrm{O}$ salt hydrates that are completely sealed in clear polycarbonate) [4]. The products have a latent thermal storage of up to $4268 \mathrm{~kJ} / \mathrm{m}^{2}$, meaning that a period of $8 \mathrm{~h}$ passes before heat is transmitted [5].

The paper describes an opportunity to develop a new type of glazing unit modified by phase change material to improve thermophysical characteristics of window component as an effective and unique type of a solar thermal energy storage system.

Considering physical characteristics, transparent or translucent building components like windows are the weakest elements of building envelope. Their $\mathrm{U}$ values are usually 4 times higher than for opaque ones causing considerable increase of heat loss during winter. In summer, relatively high solar transmittance is a source of undesirable heat gains, which result in overheating. At the same time, during the whole year the radiant asymmetry close to the window surface influences thermal comfort. On the other hand, glazing elements are necessary in buildings to provide the required amount of daylight, preferably in a diffuse form. Developed solar hybrid component would simultaneously ensure a sufficient illuminance level and stabilized thermal conditions by latent heat storage in the PCM layer.

The idea of refining thermophysical properties of glazing components, e.g., windows by PCM application is relatively brand new. However, some experimental and simulation analyses have been carried out up till now.

This concept of the PCM filled window system is viable and thermally effective. The PCM filling leads to filtering out the thermal radiation and reduces the heat gain or losses because most of the energy transferred is absorbed during the phase change of the PCM. The double glass window filled with PCM is more thermally effective than the same window filled with air [2].

To achieve the aim of the study, it has been decided to create a theoretical model of the impact of the PCM on the characteristics of the window and, as the next step, to experimentally test the model.

\section{THEORETICAL MODEL}

The first task of this model is to create a simplified measurement procedure for PCM light transmittance at different angles of the light source. The light transmittance 
through the window in which the PCM is filled depends on the location of the Sun at the sky, or the angle of incidence of the light $\alpha$ from the window plane. Assuming that the solid state of the PCM is homogeneous, the light path $d$ through PCM changes only from angle of incidence $\alpha$ (Fig. 1).

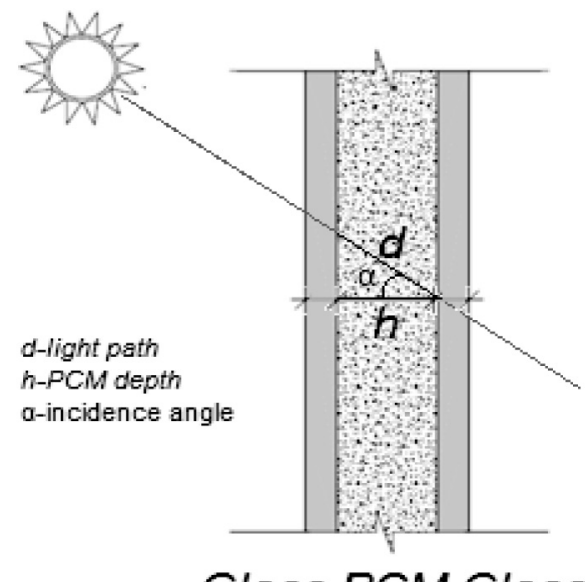

\section{Glass PCM Glass}

Fig. 1. Light path through the PCM to the angle of incidence.

Consequently, the light path $d$ through PCM depending on the angle of incidence of light on a window plane can be expressed by the following formula:

$$
d=\frac{h}{\cos \alpha},
$$

where $h$ is the gap thickness in which the phase change material is filled. This assumption allows us to study the optical properties of samples of different thickness of PCM and to express the thickness as the angle of incidence of the light source on the window plane.

The second task is to understand the influence of glass on the properties of light transmittance. In operation, the external glass receives solar radiation, where part of it is absorbed, part is reflected and the rest, about $80 \%$, is transmitted to the PCM region (initially in the solid phase) [6]. Light transmittance through glass, depending on the location of the light source, will not be significantly affected by the thickness of glass, but the reflection of light on the glass surface. Thus, it is experimentally necessary to determine light transmittance through a glass sample at different angles of incidence of light.

Knowing light transmittance through PCM samples of different thicknesses and knowing light transmittance through a glass sample at various angles and summing up the absorption of light in both materials and converting total absorbance into permeability, it is possible to obtain light transmission through a common system of glass-PCM glass. 


\section{EXPERIMENTAL SETUP}

Paraffin samples were prepared according to the following scheme: one end of the stainless steel tubes with diameter of $16 \mathrm{~mm}$ was sealed with a rubber stopper; the paraffin RT 31 was warmed until it completely melted and the molten paraffin was poured into a stainless steel tube.

To maintain the homogeneity of the samples, the tube was also heated until all of the paraffin in the tube was in the liquid state. The tube was cooled at a room temperature. When paraffin was solidified in the tube, the rubber stopper was replaced with a plastic cylinder. By pushing in a plastic cylinder to the tube, at different ends of the tube a paraffin cylinder was extruded and cut on different thicknesses. The resulting paraffin tablet was inserted between two flat glass pieces, which were first washed in acetone and placed for $10 \mathrm{~min}$ in an ultrasonic bath. An extrusion tube and samples of various thicknesses are shown in Fig. 2.

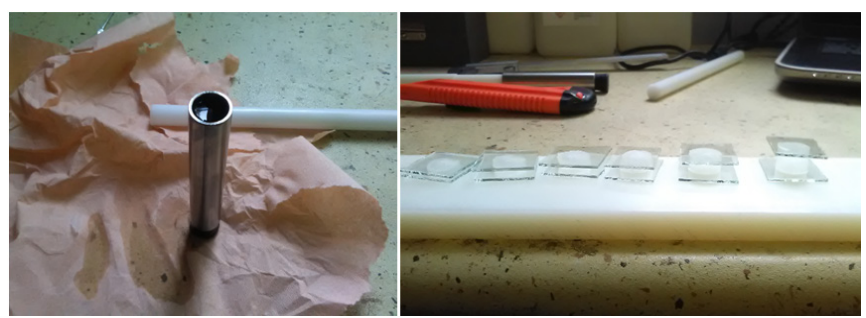

Fig. 2. Extruder with samples of various thicknesses.

Spectrophotometer Specord 210 was used to measure the total transmittance of paraffin. The total transmittance was measured by an integral sphere, in the wavelength range from 200 to $1100 \mathrm{~nm}$.

\section{RESULTS AND DISCUSSION}

\subsection{Total Transmittance Measurements for Different Thicknesses of RT35 Paraffin}

Figure 3 shows the total transmittance spectra of various thicknesses of PCM in the light wave range from 400 to $1100 \mathrm{~nm}$. It can be seen that transmittance of a single thickness sample in this light range is flat and a slight absorption peak appears at 940 $\mathrm{nm}$ [4]. As thickness of the sample increases, transmittance decreases and, accordingly, absorption increases, which was expected from the Buger-Lambert law [5].
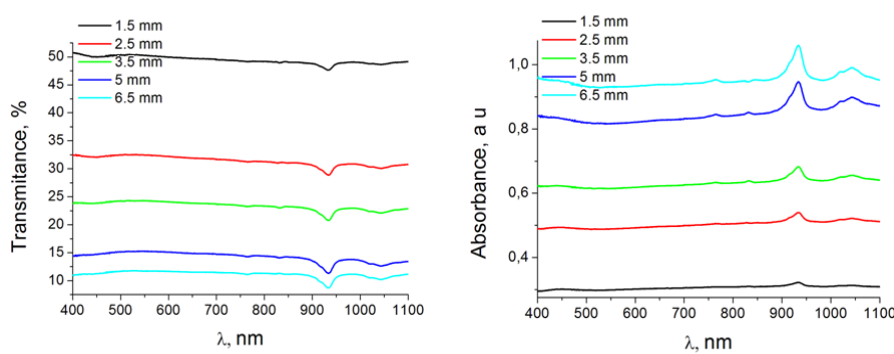

Fig. 3. Total transmittance and absorption spectra for different thicknesses of RT35 paraffin. 
Dependence of paraffin thickness and average absorption is shown in Fig. 4. In order to obtain a functional relationship between sample thickness and absorption, a regression equation was generated for the graph of Fig. 4. The following logarithmic relation was obtained:

$$
A=0.4489(d)+0.1046
$$

where $d$-sample thickness and $A$-absorbance of sample.

The correlation coefficient R2 of the regression equation obtained was 0.9917 , indicating a strong correlation.

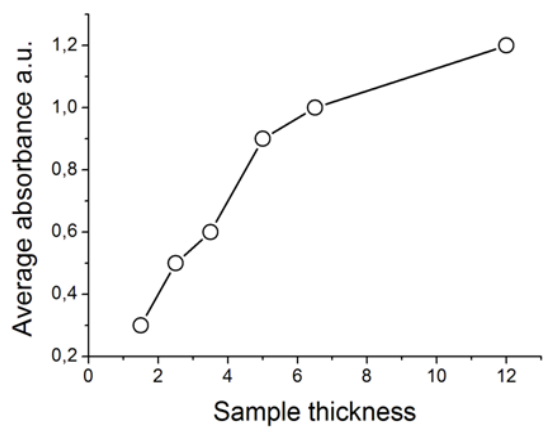

Fig. 4. Dependence of paraffin RT35 thickness and absorption.

By introducing hypothesis (1) of this paper in equation (2), it is possible to obtain a functional correlation between the absorption of the paraffin layer with thickness $h$ at different angles of incidence $\alpha$ :

$$
A=0.4489\left(\frac{h}{\cos \alpha}\right)+0.1046
$$

\subsection{Dependence of Glass Absorption on the Angle of Light Incidence}

Absorption spectra were taken for a $2 \mathrm{~mm}$ glass sample at four different angles: 10, 20, 30 and 40 degrees in the light wave range from 400 to $1100 \mathrm{~nm}$. The average absorption values obtained at four angles are shown in Fig. 5. It is seen that the absorption values exponentially increase. Compared to the absorption of paraffin, the absorption of glass is more than ten times smaller. However, at higher angles of incidence, this is significant and should be included in the model. For this purpose, in Fig. 5 the empirical curve was subjected to the regression analysis and the regression equation was generated (Fig. 5, the red curve):

$$
A=0.095+0.0023 e^{\alpha 0.069}
$$

where $A$ - glass sample absorption and $\alpha$ - light angle of incidence. 


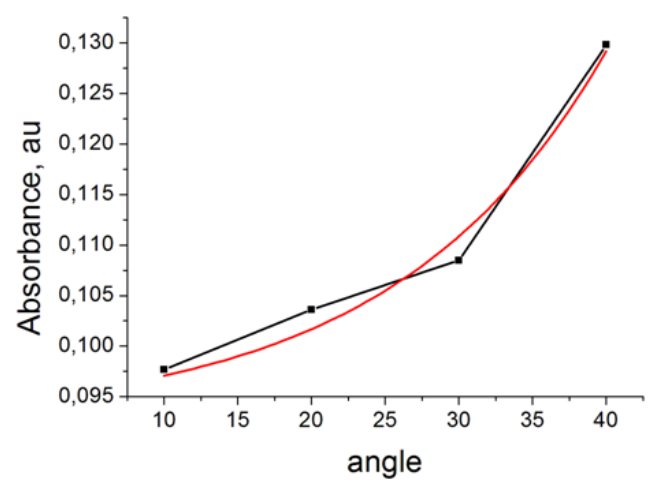

Fig. 5. Absorption of the glass sample at different angles of incidence.

\subsection{Total Absorbance and Total Transmittance of Glass and Paraffin}

Knowing the dependence between the absorption of paraffin and on the angle incidence and absorption of glass from the angle of incidence, the total absorption can be obtained by summing up the individual absorbance expressed in equations (3) and (4):

$$
A_{\text {total }}=0.4489 \mathrm{~h}\left(\frac{h}{\cos \alpha}\right)+0.0023 e^{0.069 \alpha}+0.1996 .
$$

Knowing absorption, it is necessary to calculate transmittance. Due to the fact that the absorption coefficient here is quite generalized, we first experimentally found the absorption and transmittance dependence, obtaining an empirical equation. A graph demonstrating the dependence between absorption and transmittance is presented in Fig. 6.

The regression equation is as follows:

$$
T=99.864 e^{-2.29 \cdot 9 A_{\text {total }}}
$$

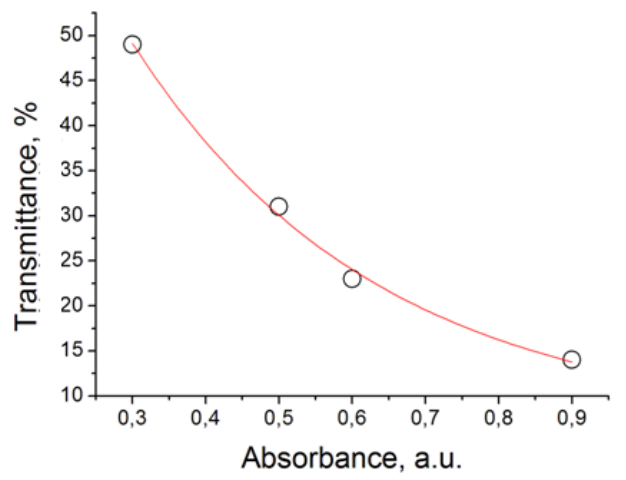

Fig. 6. Dependence between absorption and transmittance (determined experimentally as an empirical relation). 
It can be seen that the dependence shown in Fig. 6 is functional with a correlation coefficient - 1 (one). This equation is used by the apparatus to calculate transmittance from absorption data. We will also use this dependence to calculate the total absorbance transmittance.

Using equations (5) and (6), it is possible to obtain the total transmittance dependence on the angle of incidence of light and the paraffin layer thickness in the common system glass-paraffin-glass:

$$
\begin{aligned}
& T_{\text {total }}=9.864 e^{-2.299 A_{\text {Total }}}= \\
& =9.864 e^{-2.299\left(0.4489 \mathrm{~h}\left(\frac{h}{\cos \alpha}\right)+0.0023 e^{0.069 \alpha}+0.1996\right)} .
\end{aligned}
$$

To visualise the total transmittance dependence on the angle of incidence of light, transmittance was calculated according to equation (7) for a $12 \mathrm{~mm}$ paraffin layer, coated on both sides with $2 \mathrm{~mm}$ glass. The obtained data are graphically shown in Fig. 7.

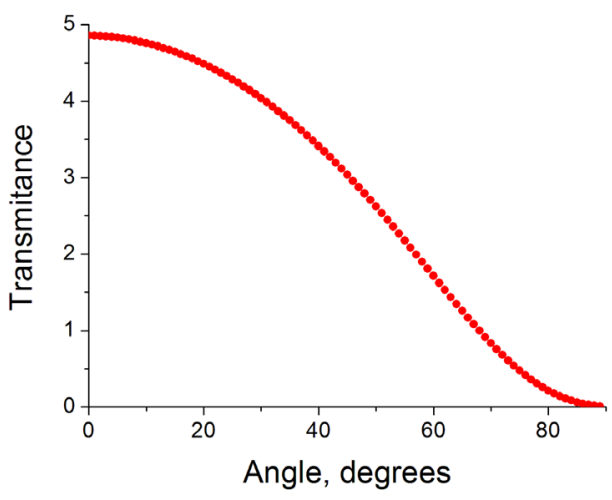

Fig. 7. The dependence of transmittance on the common system of the incident light angle, which on both sides is $4 \mathrm{~mm}$ glass and in the middle is $12 \mathrm{~mm}$ of the RT31 paraffin.

\section{CONCLUSIONS}

Theoretical models conclude that light beam shines on the PCM layer at different angles horizontally and vertically because of different sun position.

The theoretical models conclude that the luminance of the luminance through the PCM layer varies horizontally and vertically from different angles, as the sun positions differ.

According to a conventional window form, light beam goes through a thicker layer of PCM in case of perpendicular beam direction. Pure paraffin is homogeneous in the liquid phase and the solid phase of paraffin has small crystals with directorial structure. Crystal form has insignificant impact on results in case with big size samples. Hence, light reflection and absorption depend on PCM thickness and angles of incidence of the rays.

Experimental results show that according to the theory, transmittance of a single thickness sample in this light range is straight and a slight absorption peak 
appears at $940 \mathrm{~nm}$. Regression equation has been generated for determination of dependence of the tested paraffin thickness and absorption. Dependence of glass absorption on the angle of light incidence has been determined. Moreover, the total transmittance dependence on the angle of incidence of light and the paraffin layer thickness in the common system glass-paraffin-glass has been obtained.

\title{
REFERENCES
}

1. World Energy Council. (2013). World Energy Perspective. UK: World Energy Council. ISBN: 9780946121267.

2. Socaciu, L. G. (2012). Thermal energy storage with phase change material. Leonardo Electronic Journal of Practices and Technologies, 20, 75-98. ISSN 1583-1078.

3. Ismail, K. A. R., Salinas, C. T., \& Henriquez, J. R. (2008). Comparison between PCM filled glass windows and absorbing gas filled windows. Energy and Buildings 40, 710 719.

4. Fokaides, P.A., Kylili, A., \& Kalogirou, S. A. (2015). Phase change materials (PCMs) integrated into transparent building elements: A review. Materials for Renewable and Sustainable Energy, 4(2), Article 6. DOI 10.1007/s40243-015-0047-8.

5. GlassX North America. (2018). GlassX's website, Home. Available at http://www. glassxpcm.com

6. Ismail, K. A. R., \& Henriquez, J. R. (2001). Thermally effective windows with moving phase change materials curtains. Applied Thermal Engineering, 21, 1909- 1923.

7. Rubitherm. (2018). Rubiherm's website, RUBITHERM ${ }^{\circledR}$ PCM's. Available at http:// www.rubitherm.delenglish/

8. Swinehart, D. F. (1962). The Beer-Lambert law. Journal of Chemical Education, 39(7): 333. DOI: 10.1021/ed039p333.

\section{JAUNĀ TIPA STIKLOJUMA OPTISKĀS İPAŠĪBAS, KAS MODIFICĒTAS AR FĀZMAIN̦AS MATERIĀLU (TEORĒTISKĀ PIEEJA)}

\author{
M.Vanags, K.L̨ebedeva, A.Snegirjovs, G.Kaškarova, P.Šipkovs
}

Kopsavilkums

Publikācija iepazīstina ar fāzes maiņu materiālu (FMM) izmantošanu ēkas logos, kas tika pētīta ERA-NET-LAC projekta "Saules hibrīda caurspīdīgs elements siltuma enerǵijas uzglabāšanai ēkās" ietvaros. Galvenais mērksis šajā pētîjumā ir ēku energotaupības palielināšana. Lai sasniegtu uzdevuma mērksus, tika nolemts izveidot teorētisku modeli FMM ietekmei uz loga īpašībām un pēc tam eksperimentāli pārbaudīt modeli. Kā vispiemērotākais un pieejamais FMM tika izvēlēts parafīns. Tīram parafīnam ir augsta caurspīdība šķidrā fāzē un blāvi balta krāsa cietā fāzē. Publikācijā parādīti kopējās caurlaidības un absorbcijas spektru rezultāti dažādiem parafìna biezumiem ar kušanas temperatūru $35^{\circ} \mathrm{C}$, kā arī parādīts stikla parauga absorbcija ar FMM dažādos gaismas krišanas leņķos.

17.12.2018. 